WWW.icmit2014.org

ICMIT2014

23 - 25 Sep 2014, Singapore

2014 IEEE International Conference on

Management of Innovation and Technology 
IEEE Catalog Number: CFP14795-ART

ISBN: 978-1-4799-5529-9

Copyright and Reprint Permission: Abstracting is permitted with credit to the source. Libraries are permitted to photocopy beyond the limit of U.S. copyright law for private use of patrons those articles in this volume that carry a code at the bottom of the first page, provided the per-copy fee indicated in the code is paid through Copyright Clearance Center, 222 Rosewood Drive, Danvers, MA 01923. For reprint or republication permission, write to IEEE Copyrights Manager at pubs-permissions@ieee.org. All rights reserved. Copyright $@ 2014$ by IEEE. 


\section{Organizing Chair}

Kah-Hin Chai,

National University of Singapore, Singapore

\section{Program Chair}

Annapoornima M. Subramanian,

National University of Singapore, Singapore

\section{Organizing Committee}

Say Wei Foo,

Nanyang Technological University, Singapore

Ravi Sharma,

Nanyang Technological University, Singapore

Anil Varma,

Singapore Polytechnic, Singapore

团

\section{Program Committee}

Dotun Adebanjo,

University of Greenwich, United Kingdom

Samuel Bassetto,

École Polytechnique de Montréal, Canada

Alexander Brem,

University of Southern Denmark, Denmark

Ayon Chakraborty,

Indian Institute of Management Tiruchirapalli,

India

Hui-Fen Chen,

National Taipei University of

Education, Taiwan

Young Rok Choi,

National University of Singapore, Singapore

Mei-Tai Chu,

La Trobe University, Australia

Cheryl Marie Cordeiro,

University of Gothenburg, Sweden
V. Cruz_Machado,

Faculdade de Ciências e Tecnologia da Universidade

Nova de Lisboa, Portugal

Nathasit Gerdsri,

Mahidol University, Thailand

Md. Mamun Habib,

Universiti Utara Malaysia, Malaysia

Budi Hartono,

Universitas Gadjah Mada, Indonesia

Muhammad Kusumawan Herliansyah,

Gadjah Mada University, Indonesia

Ruey-Lin Hsiao,

National Cheng-Chi University, Taiwan

Chu-Chun Hsu,

Southern Taiwan University, Taiwan

Chia-Liang Hung,

National Chi Nan University, Taiwan

Supachart Iamratanakul,

Kaetsart University, Thailand

Soo Beng Khoh,

Motorola Solutions Sdn Bhd, Malaysia

Yuhong Lan,

National University of Singapore, Singapore

Carman Lee,

The Hong Kong Polytechnic

University, Hong Kong

Sungjoo Lee,

Ajou University, South Korea

Liang-Hung Lin,

National Kaohsiung University of Applied Sciences,

Taiwan

Romeo Manalo,

Manila Electric Company, Philippines

Nur Aini Masruroh,

Gadjah Mada University, Indonesia 


\section{Organizers \& CoMmitTEeS}

Michael McLean,

McLean Managment Consultants Pty Ltd and

Queensland University of Technology, Australia

Tim Minshall,

University of Cambridge, United Kingdom

Harekrishna Misra,

Institute of Rural Management Anand, India

Rozeia Mustafa,

University of Engineering \& Technology, Pakistan

Srikanth Narasimalu,

Energy research institute, Singapore

Somchai Numprasertchai,

Kasetsart University, Thailand

Ville Ojanen,

Lappeenranta University of Technology, Finland

Noritomo Ouchi,

Aoyama Gakuin University, Japan

Alan Pilkington,

Copenhagen Business School, Denmark

Yi Ruan,

National University of Singapore, Singapore

Pradyot Sahu,

3innovate, India

Christopher Seow,

University of Chester, United Kingdom

Marko Seppänen,

Tampere University of Technology, Finland

Alina Shamsuddin,

Universiti Tun Hussien Onn Malaysia, Malaysia

Ravi Sharma,

Nanyang Technological University, Singapore

Yongjiang Shi,

Cambridge University, United Kingdom

An-Jin Shie,

Nan Kai University of Technology, Taiwan
Yongyi Shou,

Zhejiang University, China

Ali Siadat,

Arts et Metiers ParisTech, France

Arif Sikander,

Murdoch University, Australia

Valdew Singh,

Nanyang Polytechnic, Singapore

Andrew Spowage,

Wood Group, Malaysia

Harm-Jan Steenhuis,

Eastern Washington University, United States

Bagyo Subagyo,

Gadjah Mada University, Indonesia

Kay Chuan Tan,

National University of Singapore, Singapore

Pei-Lee Teh,

Monash University, Malaysia

Masatsugu Tsuji,

University of Hyogo, Japan

Yasushi Ueki,

Economic Research Institute for

ASEAN and East Asia (ERIA), Indonesia

Bo Wang,

National University of Singapore, Singapore

Wei-Hsiu Weng,

National Chengchi University, Taiwan

Byungun Yoon,

Korea/Dongguk University, South Korea

Yang Yang Zhao,

Buskerud and Vestfold University College, Norway

Yuan Zhou,

Tsinghua University, China 


\section{Table of Contents}

\section{Innovation Policy and Management}

Negative Effects of Relative Proximity and Absolute Geography on Open Innovation Practices in

High-tech SMEs in the Uk

David WEISS, Tim MINSHALL

Growing Enterprises through a Technology Upgrading Strategy (GET-Up) - An Alternative Mode of

Technology Transfer

Chang Chieh HANG, Poh Kam WONG, Yuen Ping HO, Yi RUAN

The Effects of Co-opetition Capability on Innovation Practices and Competitive Advantage: A Cross-

National Comparative Study

Hoang Vuong NGUYEN, Ja-Shen CHEN, Chung-Shing LEE

Growth Factors Model Building and Empirical Analysis of Small and Medium Sized Technology

Enterprises

Danyang WANG, Luxiu ZHANG, Yuming ZHANG

Conceptual Model Development of Local Cultural Brand Experiences

Ching-Yu LIEN, Eric NG

\section{Technology Strategy and Management in Developing Countries}

Patterns of Innovation of a Successful Latecomer Firm: A Longitudinal Analysis of the Case of

Huawei

Jian ZHANG, Pierre VIALLE

What Drives Venture Capital Fundraising in India: An Empirical Analysis of Systematic and Nonsystematic Factors

Kshitija JOSHI, M.H. BALA SUBRAHMANYA

Product Modularity and Supply Chain Collaboration: An Empirical Study of Firm Performance for 221 Chinese Manufacturing Industries

Shuiyin ZHOU, Zonghong GU, Jiafeng YUAN

How to Use Improvement Gap Analysis to Identify Which Incremental Innovations Should Be Incorporated Into Products: Managerial Recommendations

Gerson TONTINI, Klaus Solberg SØILEN

Innovation and Production Management Through a Just in Sequence Strategy in a Multinational Brazilian Metal-mechanic Industry

Eric Charles Henri DORION, Julio Cesar Ferro GUIMARAES, Eliana Andrea SEVERO, Zaida Cristiane REIS, Pelayo MUNHOZ OLEA

\section{Human Capital for Innovation}

Where Do Breakthrough Ideas Come From? Characteristics of Scientists' Research Behaviors Le WANG, Jun LIN, Wentian CUI

Does Academic Breakthrough Lean on the Shoulders of Giants? A Bibliometric Investigation of Social Science

Yanjun QIAN, Xiamin YAN, Jianmei LI, Jun LIN 


\section{Knowledge Management}

Organizational Ambidexterity in Construction Projects

Freeing Entities of Attributes: Revisiting Database Normal Forms from an Organizational Knowledge

Perspective Marc IDELSON, Christophe DANY

Agents-based Model of Knowledge Sharing Among Personnel with Varying Learning Rate in

The Knowledge Exchange: A Platform for Pooling Technology Intelligence Knowledge Between

Practitioners, Researchers, and Technologists

Guenther SCHUH, Patrick KABASCI, Susanne AGHASSI, Toni DRESCHER

Influencing Factors and Requirements for Designing Customized Technology Transfer Portals Guenther SCHUH, Susanne AGHASSI, Bernd SCHNEIDER, Patrick BARTELS

\section{Intellectual Property Management}

Excavating the Role of NPEs in the Innovation Process: Did We Start a Mission Possible? Rob DEKKERS, Frank TIETZE

Using Web of Science as the Indicator for Patenting Strategies Hoi Yan Anna FONG, Shang-Jyh LIU

The Worldwide IP Economy - Reality or Utopia?

\section{Design Thinking and Management}

Integration of Design Thinking with Strategy and Innovation in an Enterprise Context Tirumala Rao VINNAKOTA, Narayana MANDALEEKA

Design Factors of Mobile Game for Increasing Gamer Chih-Lung CHOU, Chia-Liang HUNG, Ying-Hsun HUNG

Project Performance Indicators of Engineering Design Groups: Evaluation and Proposed Improvement Budi HARTONO, Irawan MUHAMAD

Determined the Critical Factors of Facial Mask Products and Size Design Bor-Shong LIU, Siou-Ning LIN, Ching-Wen LIEN, Hsin-Hung LAI

Ensuring Quality in Process Design: Tracing Requirements to People and Systems 


\section{Innovation Policy and Management in Public Sector}

Purpose and Experience of Patenting and the Processes of Patent Management Employed by

University Scientists

Teh-Yuan CHANG, Chung-Yuan TSAY

A Preliminary Examination of Stimulating and Building University-Industry Collaborative Works at a

Public University

Ng KIM-SOON, Isabella ANAK NIKOL, Wahid RAZZALY, Abd Rahman AHMAD

Knowledge and Technology Transfer Barriers - Polish Universities Perspectives Dariusz M. TRZMIELAK, Malgorzata GRZEGORCZYK

The Development of a KIM Behavioural Framework to Support Knowledge Transfer in the Defence Sector - A Case Study Approach Roger DARBY, Charles KIRKE

Innovation Process in ASEAN Firms: Focus on Internal Capability, External Linkages and

Transmission Channels

Masatsugu TSUJI, Yasusi UEKI, Hiroki IDOTA, Masaru OGAWA

\section{Innovation \& IT}

Telecommuting: Impact on Productivity of Telecommuters

Adeel AHMED, Azam ISHAQUE, Tahir NAWAZ, Yusra ALI, Farah HAYAT

Innovation and the Cloud: A Review of Literature

Surya KARUNAGARAN, Saji K MATHEW, Franz LEHNER

The Connection of the Stakeholder Cooperation Intensity and Team Agility in Software Development Tomi JUHOLA, Man Hang YIP, Sami HYRYNSALMI, Tuomas MÄKILÄ, Ville LEPPÄNEN

Investigating the Effects of Information Quality and Perceived Risk on Information Adoption on

Travel Websites

Shun-Yao TSENG, An-min KUO

Information and Communication Technology Introducing Efficiency in Emergency Medical Services Adeel AHMED, Azam ISHAQUE, Tahir NAWAZ

\section{Entrepreneurship}

Less Becomes More: Resource Reconstruction in Entrepreneurial Bricolage Ruey-Lin HSIAO, Chi-Hsu LIAO, Chun-Fong YANG

A View on Science-based Start-ups as Innovation Ecosystems: Exploring Functions of Basic

Mechanisms

Saku MÄKINEN

How Does Effectual Logic Impact Survival of High-tech Startups in an Emerging Economy? -

Evidence from 99tests.com Case Study H S KRISHNA, M.H. BALA SUBRAHMANYA

Entrepreneurship, Entrepreneurial Enterprise, and Valuation Issue Rongning CAO, Zeyong TIAN 
Innovation

Phannaphatr SAVETPANUVONG, Pakorn PANKASEM

\section{New Product Development}

Recreating Something from Everything: New Product Innovation through Social Construction of

Frugal Resources

Ruey-Lin HSIAO, Su-Hua OU, Huan-Hung CHEN

Research on Generation Ideas Process for Product Radical Innovation Based on Technology

Evolution Theory

Enshun PING, Runhua TAN, Jianhui ZHANG, Bo HAN

Innovation during the Supplier Selection Process: A Novel Multi-Stage Process Case Alan PILKINGTON, Isabel PEDRAZA

Method for Product Integrated Innovation Based on Functional Combination and TRIZ Fang LIU, Xuepeng LI, Fei YU, Enshun PING

A Vision Oriented Approach Proposed \& Compared

Madhumita SINGHA, Vandana BHATTACHERJEE, Rupa MAHANTI

\section{Technology Intelligence and Planning}

Disruption Recovery Modeling in Supply Chain Risk Management

The Development of a Supply Chain Model for Tourism Crisis Management Walter S. L. FUNG, Richard Y. K. FUNG

Quantitative Model of the Technology Lifecycle for Forecasting the Maturity of Manufacturing

Technologies

Josef GREITEMANN, Benjamin STAHL, Nicolas Vincent MICHELS, Boris LOHMANN, G. REINHART

Personalized u-Commerce Recommending Service using Weighted Sequential Pattern with Timeseries and FRAT method

Young Sung CHO, Keun Ho RYU, Kwang Sun RYU, Song Chul MOON

Simulation-based Training Model to Develop Project Management Competencies Arief RAHMANA, Mustofa KAMIL, Endang SOEMANTRI, Ayi OLIM

\section{Service Innovation}

Study of Service Innovation on School Bullying Treatment with Inviting Knowledge Management Features Yu-Tso CHEN, Ching-Ching LI

A Study on Operating Pattern of Restaurant Franchise from the Service-Dominant Logic Perspective Ya-Lan CHIN, Feng-Shang WU

Conceptual Model for Reducing Outpatient Care Waiting Times in Teaching Hospital in Indonesia Oktri Mohammad FIRDAUS, T.M.A. Ari SAMADHI

Maintenance Innovations - Types, Patterns and Emerging Trends Ville OJANEN 


\section{Innovation Policy and Management}

Innovation, Organization Transformation and Human Resource Management: A Discourse Analysis

Study of Swedish Managers in Singapore

Cheryl Marie CORDEIRO

The Threshold Effect between Technology Gaps Based on the Heterogeneity

Zeyong TIAN, Tao LU

Technology Management and the Firm Arif SIKANDER

Quo Vadis Third Party Payment After Deregulation of Bank Act? A Qualitative Observation on the Trend of E-Commerce Patents in Taiwan Sung-Min LIN, Anne Yen-Ching LIU

Knowledge Internalization for Individual Innovation Capability Augustina Asih RUMANTI, Trifenaus Prabu HIDAYAT

Total Innovation Management Paradigm for Firm Innovation System Qingrui XU, Zhiyan WU, Suping ZHANG, Siyu LIU

Accumulation and Innovation in a Capability Leveraging Perspective: Review of Theories and Evidence Qingrui XU, Siyu LIU, Suping ZHANG

Corporate Social Responsibility and Innovation: Evidence from Emerging Economies Xuefeng LIU, Fangning XU

Does ICT Effectively Contribute to the Delivery of Mass Education in Developing Countries? Ravi SHARMA, Zhang Hao GOH, Guangyuan SUN, Wei Ta HO

Factors Affecting New Project Delays in Saudi Arabian Manufacturing Organisations Aminul ISLAM, Ali AL OWAD, Omar BADRAIG, Lin MA, Azharul KARIM

Intellectual Property Creation of MNCs in Developing Countries - The Cases of China and Thailand Masayuki KONDO

2012: The Actors of Innovation in the Province of Quebec, Canada Gabriela Cristina LAIN, Eric Charles Henri DORION, Cleber Cristiano PRODANOV, Francois COALLIER, Pelayo MUNHOZ OLEA

Government Interventions and the Formation of Innovation Cluster: A Case Study of Guangdong

Real Faith Science Park Hanwei ZHANG, Xiaohong CHEN, Yuan ZHOU

The Impacts of National Characteristics on Adoption and Substitution of Innovation Yudai ARAI, Tomoko KAJIYAMA, Noritomo OUCHI

A Causal Model of the Bicycle Industry Development - The Case in Taiwan Hui-Hua HUANG 


\section{R\&D Management}

How Technology Search Facilitate Technological Innovation Capability Reconfiguration: Empirical

Study under Emerging Economy

Qingrui XU, Litian CHEN

Aligning Innovation Ecosystem Strategies with Internal R\&D

Petra BOSCH-SIJTSEMA, Jan BOSCH

Contextual Ambidexterity in the Development of an R\&D Oriented Company

Hideko KONO

A Pyramidal Model for Initial Problem Situation Analysis Process

Bo HAN, Jianhui ZHANG, Kechang LIU, Lizhen JIA, Rui LIANG

Process Innovation in Partnering: A Framework for Aligning Organizational Cultures in the

Malaysian Construction Industry

Faizatul Akmar ABDUL NIFA, Vian AHMED

\section{Technology Strategy and Management}

Study on Financial Support Model of Enterprises Low-carbon Technology Innovation

Luxiu ZHANG, Yuming ZHANG, Danyang WANG

Development Assessment and Strategy Planning in Mobile Computing Industry

Wei-Hsiu WENG, Woo-Tsong LIN

Research on the Interactive Relationship between Corporate Governance Culture and Accounting

Information Disclosure

Han QIANQIAN

The Forecasting Model of 4G LTE Implementation in Indonesia

Muhammad SURYANEGARA, Achmad RAMADHAN, Afid Kurnia AKBAR, Muhamad ASVIAL

New Changes in Organizational Design to Instigate Co-creation Dynamics and Innovation: A Model Based on Online Multiplayer Games

Mateus PANIZZON, Lucas Bonacina ROLDAN, Margarete Argugeri MENEGOTTO, Eric Charles Henri

DORION

\section{Technology Intelligence and Planning}

A DSS Framework for Integrating Inventory Management and Purchasing in ATO Production

Environment

Sumin JEON, Chin Soon CHONG, Ramasamy S. VALLIAPPAN

A Discrete Particle Swarm Optimization for Disassembly Sequence Planning
Choosak PORNSING, Arnat WATANASUNGSUIT

Improving Medical Tourism Services Based on a Hybrid MCDM Model Combined by DANP and VIKOR Techniques

Ying-Hsun HUNG, Jung MA, Jerome Chih-Lung CHOU, Gwo-Hshiung TZENG

Measuring Performance of Reverse Supply Chains in a Computer Hardware Company Maulida BUTAR BUTAR, D. SANDERS, G. TEWKESBURY 


\section{Sustainable Development \& Environmental Protection}

Sustainability Strategies and Reverse Logistics Management: A Contingent Link Chien-Lung HSU, Yi-Chuan LIAO

Enabling Green Design with TRIZ

Carman LEE, Marcus, Jia En TAI

Building a Novel Model of Performance Measurement System for Corporate Social Responsibility

Towards Sustainable Development Astrie KRISNAWATI, Gatot YUDOKO, Yuni Ros BANGUN

Predicting the Success Possibility for Green Supply Chain Management Implementation Rakesh Kumar MALVIYA, Ravi KANT

Strategic and Adaptive Knowledge-Environment-Technological (SAKET) Management System for Sustainable Reuse of Dredged Marine Soils Chee-Ming CHAN, Alina SHAMSUDDIN, Azeanita SURATKON

\section{Quality Management and Innovation}

Better Improvement Management to Overcome Inventory, Transportation, and Unnecessary Motion

Waste in Retail Stores

Yusepaldo PASHARIBU, Ferry JIE, Joshua JACOBS, Andrew PUNTURIERO

The Effect of TQM Implementation Towards Productivity of Employees Using Structural Equation Modeling (SEM) Analysis Method in PT XYZ

Nilda Tri PUTRI, Haesti Sujita DARMA

Performance-Based Maintenance Contract For Equipments Used In Mining Industry Hennie HUSNIAH, Udjianna PASARIBU, Andi CAKRAVASTIA, Bermawi P. ISKANDAR

Improving the Efficiency of Taguchi with Six Sigma - A Case Study of Hand Tool Drilling Process Production

En-Wei LIN, Meiling WONG 


\title{
The Effect of TQM Implementation towards Productivity of Employees Using Structural Equation Modeling (SEM) Analysis Method in PT XYZ
}

\author{
Nilda Tri Putri ${ }^{1}$, Haesti Sujita Darma ${ }^{2}$ \\ Dept. of Industrial Engineering, Faculty of Engineering, \\ Andalas University, Padang, West Sumatra, Indonesia \\ ${ }^{1}$ Email: nilda@ft.unand.ac.id,nilda_tp@yahoo.com ${ }^{12}$ Email: hestihaes@yahoo.com²
}

\begin{abstract}
This paper analyzes influences of TQM's implementation on employees productivity in PT XYZ, analyze predominant factor in order to establish the success of TQM's implementation as well as predominant factors affecting employees productivity. The research method used the result of interview and questionnaire. Number of respondents is $\mathbf{1 0 0}$ and using analysis method of Structure Equation Modeling (SEM) by software Linear Structural Relationship (LISREL) 9.0. The results showed the influences of TQM's implementation on employees and to specify the predominant factor in the implementation of TQM's and employees productivity. This paper is useful for manufacture companies in Indonesia. Because the variables used in this research are based on the empirical research. TQM's was measured six indicators and the work productivity of employee is measured by four indicators.

Keywords - Quality improvement, Work productivity, SEM methods
\end{abstract}

\section{INTRODUCTION}

Manufacturing and service companies have implemented a system which aims to improve the quality either from aspect of product/service or management aspect. The system is known as Total Quality Management (TQM). An effective TQM's implementation is desired to give positive influences on company's productivity. PT XYZ has implemented TQM since 2000. TQM's implementation is a form of PT XYZ's commitment in order to create quality products and a proper management system. TQM is profiting-eachother cooperation from people in organization and related to business process to yield product and service' value which exceed consumers' needs and hopes [1]. Whereas, according to Juran in [2], TQM will be implemented whether following three managerial processes e.g. quality planning, quality control, and quality improvement. The process development by Juran himself is known as “Trilogy of Juran". In TQM's implementation in PT XYZ there is a problem, unachievable target as established target. Unachievable target depicts that there is a decreasing employees performance that causes on decreasing employees productivity. Improvement of employees productivity in a company could be done with one way, implement TQM. However, in order to implement TQM, it needs to identify predominant factors which take major roles in the success of TQM's implementation. Besides, predominant factors which determine successful TQM implementation also need to be known so that it is right on target to improve employees productivity. Human resource is a major factor in order to establish the success or failure of product's quality improvement so that it is necessary to the company to pay attention to factors affecting employees productivity. There are many factors which can affect employees productivity either related to workforces or related to company's environment and the government policies as a whole.

This research aims to analyze the influence of TQM's implementation on employees productivity in PT XYZ. The success of the implementation is affected by indicators influencing TQM. According to Ibrahim [3], TQM's implementation is measured by six indicators e.g. human resources, standard, tools, organization, internal audit, and training \& education. Whereas in Sinungan [4], employees productivity are measurable using four indicators e.g. employees work environment and work relations. The magnitude influence given to implementation of TQM in PT XYZ on employees productivity is measured using an analysis method of Structural Equation Modeling (SEM). These research indicators are referred to previous research, as seen on both Table I and Table II.

Structural Equation Modeling is a statistical method used to analyze relationship pattern between latent variable and its indicator, one latent variable with others, also direct measurement. Statistical analysis method in the research is done using Structural Equation Modeling (SEM) with software LISREL.

\section{METHODOLOGY}

Respondents in this research are employees of PT XYZ. Data collecting is conducting by two steps. First, questionnaires are spread out to 30 respondents. Then, validity and reliability tests are conducted. If data collected is invalid or not reliable so that the questionnaires have to be revised, then, step 2 questionnaires are spread out to obtain total number of 100 data.

Variables used in the research are latent variables and manifest variables. Latent variables are original variables that can't be measured directly, but through the variables indicator. In contrast, manifest variables are measurable variables. Both research model of latent variables and manifest variables are as seen on Table III. 
Table I. Research Indicators Determination of Total Quality Management

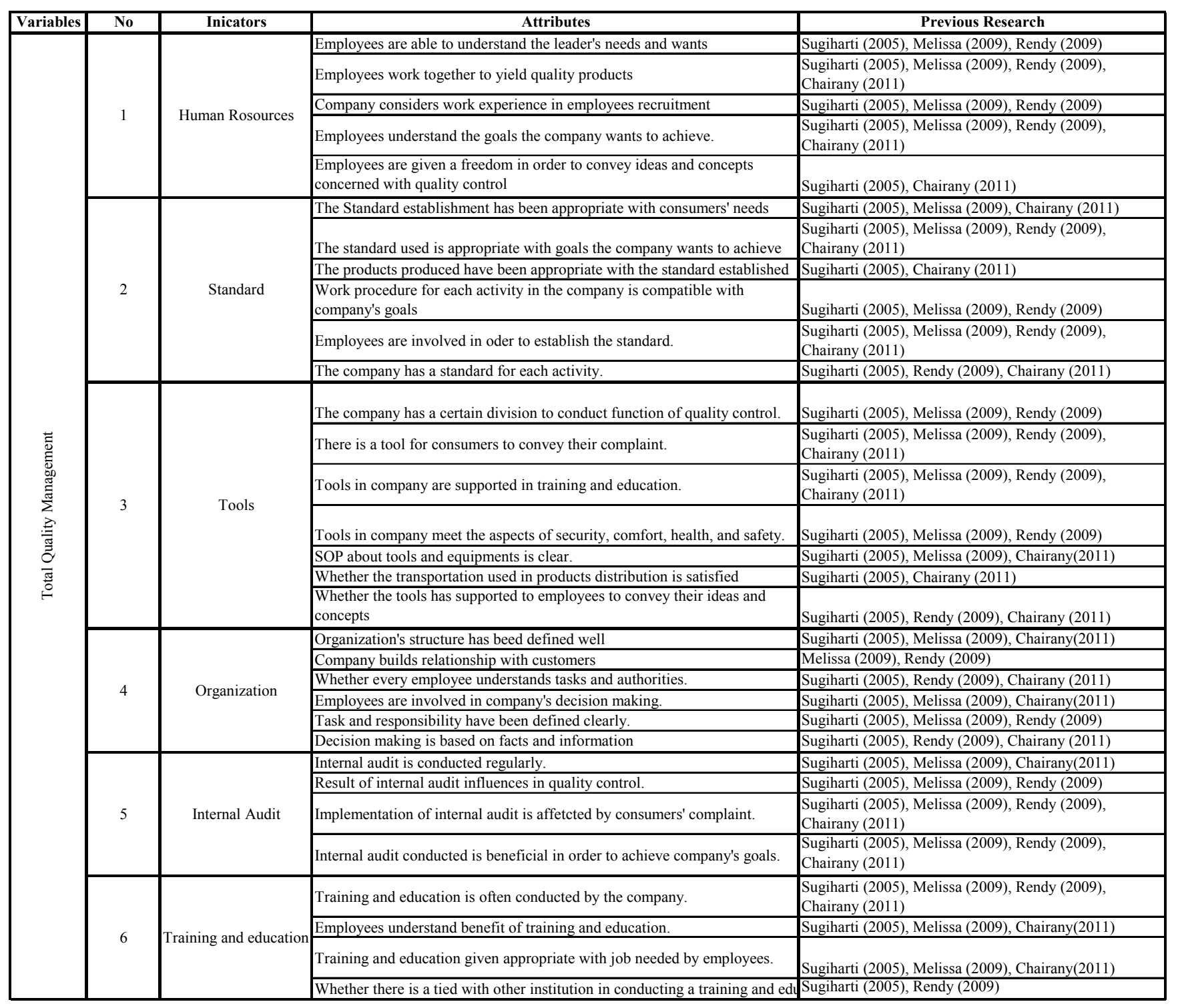

Hypothesis of the research is prepared based on desirable research objective. Research hypothesis formulation as follow:

$\mathrm{H}_{1}$ : there is a positive relationship between implementation of Total Quality Management in PT XYZ and employees productivity.

$\mathrm{H}_{2}$ : there is a positive relationship between human resources, tools, standard, organizing, internal auditing, a training \& education on TQM's implementation.

$\mathrm{H}_{3}$ : there is positive relationship between work willingness, work ability, work environment, and work relations with employees productivity in PT XYZ.
After variables of implementation used in the research, then the relationship between both latent variables can be made in mathematical notation form, in two types equation form:

1. Structural Model Mathematical Notation

$\mathrm{PKK}=y \mathrm{MKT}+\mathrm{C}$

2. Measurement Model Mathematical Notation
a. $\mathrm{SDM}=\lambda \mathrm{SDMMKT}+\delta$
b. $\mathrm{STD}=\lambda \mathrm{STDMKT}+\delta$
c. $\quad \mathrm{SRN}=\lambda \mathrm{SRN} \mathrm{MKT}+\delta$
d. $\quad \mathrm{ORG}=\lambda \mathrm{ORGMKT}+\delta$
e. $\quad \mathrm{AUI}=\lambda$ AUI MKT $+\delta$
f. $\quad$ DIK $=\lambda$ DIK MKT $+\delta$
g. $\quad \mathrm{KMK}=\lambda \mathrm{KMK}$ PKK $+\varepsilon$
h. $\quad \mathrm{KPK}=\lambda \mathrm{KPK} \mathrm{PKK}+\varepsilon$ 
i. $\quad \mathrm{LJK}=\lambda \mathrm{LJK}$ PKK $+\varepsilon$

j. $\mathrm{HBK}=\lambda \mathrm{HBK}$ PKK $+\varepsilon$

Table II. Research Indicators Determination of Employees Productivity

\begin{tabular}{|c|c|c|c|c|}
\hline Variables & No & Indikator & Atribut & Penelitian Terdahulu \\
\hline \multirow{20}{*}{ 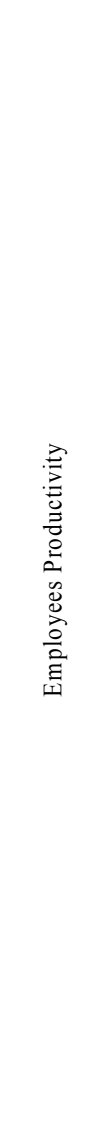 } & \multirow{5}{*}{1} & \multirow{5}{*}{$\begin{array}{l}\text { Emlpoyees wiliing to } \\
\text { work }\end{array}$} & I am responsible on the job I do. & $\begin{array}{l}\text { Melissa (2009), Indraswari (2007), Sugiharti (2005), } \\
\text { Chairany (2011) }\end{array}$ \\
\hline & & & I am always serious in conducting a work. & $\begin{array}{l}\text { Melissa (2009), Indraswari (2007), Sugiharti (2005), } \\
\text { Chairany (2011) }\end{array}$ \\
\hline & & & I always obey the rules of work. & Melissa (2009), Indraswari (2007), Chairany (2011) \\
\hline & & & I always follow activities conducted by the company. & $\begin{array}{l}\text { Melissa (2009), Indraswari (2007), Sugiharti (2005), } \\
\text { Chairany (2011) }\end{array}$ \\
\hline & & & I always work seriously, even though there is no supervision from the boss. & Melissa (2009), Indraswari (2007), Sugiharti (2005) \\
\hline & \multirow{5}{*}{2} & \multirow{5}{*}{ Employees ability } & I can work properly. & Melissa (2009), Indraswari (2007), Chairany (2011) \\
\hline & & & I can finish the task on time. & Melissa (2009), Sugiharti (2005), Chairany (2011) \\
\hline & & & I can carry out task and responsibility as my job description. & Melissa (2009), Indraswari (2007), Chairany (2011) \\
\hline & & & I always struggle to give the best effort to the company. & Melissa (2009), Sugiharti (2005), Chairany (2011) \\
\hline & & & I often ask for advice to co-workers or boss about difficult work. & Melissa (2009), Indraswari (2007), Sugiharti (2005) \\
\hline & \multirow{5}{*}{3} & \multirow{5}{*}{$\begin{array}{l}\text { lingkungan kerja } \\
\text { karyawan }\end{array}$} & I am responsible on the job I do. & $\begin{array}{l}\text { Melissa (2009), Indraswari (2007), Sugiharti (2005), } \\
\text { Chairany (2011) }\end{array}$ \\
\hline & & & I am always serious in conducting a work. & $\begin{array}{l}\text { Melissa (2009), Indraswari (2007), Sugiharti (2005), } \\
\text { Chairany (2011) }\end{array}$ \\
\hline & & & I always obey the rules of work. & Melissa (2009), Indraswari (2007), Chairany (2011) \\
\hline & & & I always follow activities conducted by the company. & $\begin{array}{l}\text { Melissa (2009), Indraswari (2007), Sugiharti (2005), } \\
\text { Chairany (2011) }\end{array}$ \\
\hline & & & I always work seriously, even though there is no supervision from the boss. & Melissa (2009), Indraswari (2007), Sugiharti (2005) \\
\hline & \multirow{5}{*}{4} & \multirow{5}{*}{$\begin{array}{l}\text { Employees work } \\
\text { relation }\end{array}$} & I can cooperate with others. & Melissa (2009), Indraswari (2007), Sugiharti (2005) \\
\hline & & & I often ask for help to finish my task. & Melissa (2009), Indraswari (2007), Chairany (2011) \\
\hline & & & I am ready to give a grant to finish task which is not mine. & $\begin{array}{l}\text { Melissa (2009), Indraswari (2007), Sugiharti (2005), } \\
\text { Chairany (2011) }\end{array}$ \\
\hline & & & I always report result of work as the truth. & $\begin{array}{l}\text { Melissa (2009), Indraswari (2007), Sugiharti (2005), } \\
\text { Chairany (2011) }\end{array}$ \\
\hline & & & $\begin{array}{l}\text { aya memiliki hubungan yang baik dengan rekan kerja. I have a good } \\
\text { relationship with co-workers. }\end{array}$ & Melissa (2009), Sugiharti (2005), Chairany (2011) \\
\hline
\end{tabular}

Table III. Research Variables in PT XYZ

\begin{tabular}{|c|c|c|}
\hline Latent Variables & Manifest Variables & Variables Code \\
\hline \multirow{6}{*}{$\begin{array}{c}\text { Total Quality } \\
\text { Management } \\
(\mathrm{MKT})\end{array}$} & $\begin{array}{l}\text { Human Resources } \\
\text { (SDM) }\end{array}$ & $\mathrm{X} 1$ \\
\hline & \begin{tabular}{|l|} 
Standard (STD) \\
\end{tabular} & $\mathrm{X} 2$ \\
\hline & \begin{tabular}{|l} 
Tools (SRN) \\
\end{tabular} & $\mathrm{X} 3$ \\
\hline & Organisasi (ORG) & $\mathrm{X} 4$ \\
\hline & Internal Auditing (AU & $\mathrm{X} 5$ \\
\hline & $\begin{array}{l}\text { Training and } \\
\text { Education (DIK) } \\
\end{array}$ & X6 \\
\hline \multirow{4}{*}{$\begin{array}{c}\text { Employees } \\
\text { Productivity (PKK) }\end{array}$} & $\begin{array}{l}\text { Willingness to Work } \\
(\mathrm{KMK})\end{array}$ & Y1 \\
\hline & $\begin{array}{l}\text { Employees ability to } \\
\text { work (KPK) }\end{array}$ & Y2 \\
\hline & \begin{tabular}{|l|} 
Employees work \\
environment (LKK)
\end{tabular} & Y3 \\
\hline & $\begin{array}{l}\text { Employees work } \\
\text { relationship (HKK) }\end{array}$ & Y4 \\
\hline
\end{tabular}

\section{RESULTS}

Result of the research can be begun from data processing result of preliminary questionnaires test using Microsoft Excel 2007 to make tabulation of descriptive data and data adequacy test, and SPSS 16.0 for Windows to test validity and reliability. The preliminary test aims to know whether questionnaires are feasible and accurate to spread out to consumers in an adequate amount. Validity and reliability tests are conducted on data collected from questionnaires dissemination on 100 employees of PT XYZ. Value of r-table to data $n=100$ and error rate $5 \%$ is about 0.195 [10]. If the result of validity test conducted to all first step questionnaires data are known that all data exist up to 0.195 , so it can conclude that research questionnaires to the employees is valid and it can be used to gain second step data. Reliability testing questionnaires also uses software SPSS 16.0 with $n=100$. According to Sugiyono [11], question instrument are reliable whether value of alpha's coefficient (Cronbach's alpha) is not 
lower than 0.60 , so that the questionnaires are feasible to disseminated. As well as result of adequacy test of questionnaires that are known value $\mathrm{N}>\mathrm{N}^{\prime}$. It can be concluded that the data is sufficient and able to represent population existing, so that next data processing can be conducted.

After conducting preliminary test on questionnaires data then it can continue by implementing analysis method of SEM, that is:

\section{Model Specification}

This step is related to preliminary forming of structural equation before estimation conducted. Steps of model specification can be shown as follow:

a. Determining Latent variables

Latent variables in the research as follow:

1. Total Quality Management (MKT)

These variables are independent latent variables because they are a kind of variables influencing another latent variable, namely PKK.

2. Employees Productivity (PKK)

These variables are dependent latent variables because being influenced by other variable, namely MKT

b. Determining Manifest Variables

Manifest variables are directly measurable variables.

Manifest variables which are used in the research as shown in Table IV.

Tabel IV. Manifest Variables in the Research

\begin{tabular}{|c|c|c|}
\hline No & $\begin{array}{c}\text { Indicators of } \\
\text { MKT (X) }\end{array}$ & $\begin{array}{c}\text { Indicators of } \\
\text { PKK (Y) }\end{array}$ \\
\hline 1 & SDM (X) & KMK (Y1) \\
\hline 2 & STD (X2) & KPK (Y2) \\
\hline 3 & SRN (X3) & LKK (Y3) \\
\hline 4 & ORG (X4) & HKK (Y4) \\
\hline 5 & AUI (X5) & \\
\hline 6 & DIK (X6) & \\
\hline
\end{tabular}

c. Determining Structural Model

Structural model in the research is

$\mathrm{PKK}=\mathrm{y} \mathrm{MKT}+\mathrm{c}$

d. Determining Measurement Equation Notation

Based on structural model and manifest variables' determination to the respective variable, it can determine measurement equation notation to variables of MKT and PKK. There are several equation notations in the research, as follow:

1. $\mathrm{SDM}=\lambda \mathrm{SDMMKT}+\delta$

2. $\mathrm{STD}=\lambda \mathrm{STD} \mathrm{MKT}+\delta$

3. $\mathrm{SRN}=\lambda \mathrm{SRN} \mathrm{MKT}+\delta$

4. $\mathrm{ORG}=\lambda \mathrm{ORGMKT}+\delta$

5. $\mathrm{AUI}=\lambda \mathrm{SAUI} \mathrm{MKT}+\delta$

6. $\mathrm{DIK}=\lambda \mathrm{DIK} \mathrm{MKT}+\delta$

7. $\mathrm{KMK}=\lambda \mathrm{KMK} \mathrm{PKK}+\varepsilon$

8. $\mathrm{KPK}=\lambda \mathrm{KPK} \mathrm{PKK}+\varepsilon$

9. $\mathrm{LJK}=\lambda \mathrm{LJK} \mathrm{PKK}+\varepsilon$

$10 . \mathrm{HBK}=\lambda \mathrm{HBK}$ PKK $+\varepsilon$

\section{Model Estimation}

Step of estimation is done to obtain value of factors existed in the model. Estimation method used is Maximum Likelihood. Result of SEM estimated is in the form of standardized solution, diagram of path. Processing result uses LISREL Student 9.0 to know level of closeness of relationship between variables existed in the model.

The model estimation is processing result of all questions in questionnaires which are manifest variables of each latent variable in the research. There are several questions in these research variables, as following in Table V.

Table V. Variables of Research

\begin{tabular}{|c|l|l|}
\hline Research Variables & \multicolumn{1}{|c|}{ Indicators Measured } & \multicolumn{1}{c|}{ Number of Questions } \\
\hline \multirow{4}{*}{$\begin{array}{c}\text { Total Quality } \\
\text { Management (MKT) }\end{array}$} & Human Resources (SDM) & $1,2,3,4,5,6$ \\
\cline { 2 - 3 } & Standard (STD) & $7,8,9,10,11,12$ \\
\cline { 2 - 3 } & Tools (SRN) & $13,14,15,16,17,18,19,20$ \\
\cline { 2 - 3 } & Organisasi (ORG) & $21,22,23,24$ \\
\cline { 2 - 3 } & Internal Auditing (AUI) & $25,26,27$ \\
\cline { 2 - 3 } $\begin{array}{c}\text { Employees Productivity } \\
\text { (PKK) }\end{array}$ & Training and Education (DIK) & $28,29,30,31$ \\
\cline { 2 - 3 } & Employees Willingness to Work (KMK & $32,33,34,35,36$ \\
\cline { 2 - 3 } & Employees ability to work (KPK) & $37,38,39,40$ \\
\cline { 2 - 3 } & Employees work environment (LKK) & $41,42,43,44$ \\
\hline \multirow{2}{*}{$\begin{array}{l}\text { Employees work relationship (HKK) } \\
\text { (PK) }\end{array}$} & $45,46,47,48,49$ \\
\hline
\end{tabular}

Based on the questionnaires, data will be processed using software of LISREL Student 9.0, and then it will yield model estimation, as shown by Figure 1.

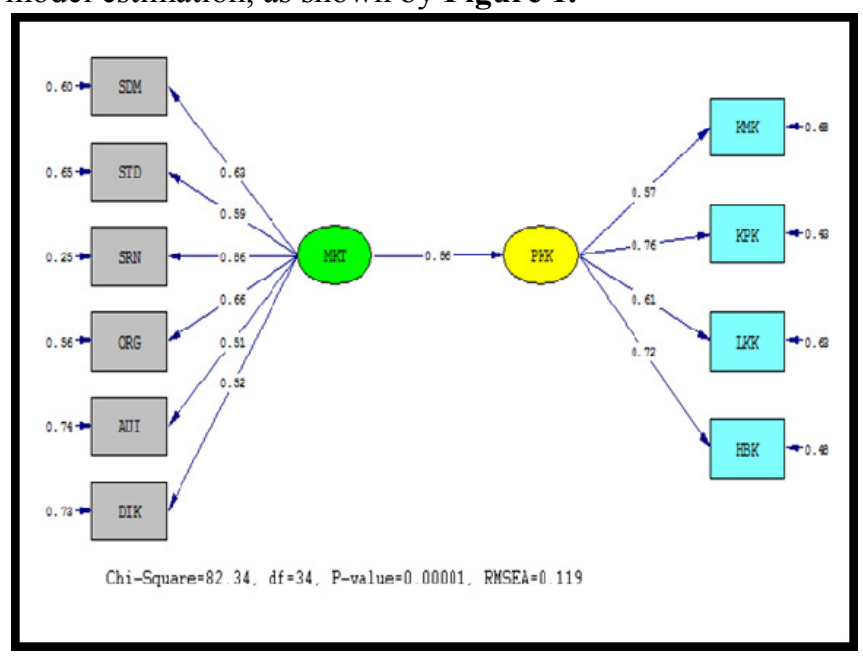

Figure 1 Structural Estimation Value

Value of loading factor and determination coefficient $\left(\mathrm{R}^{2}\right)$ can be obtained from estimation result. Loading factor is a coefficient showing the magnitude of indicator's variable contribution level in forming latent variable. Value of $\mathrm{R}^{2}$ of every coefficient is determinant coefficient that is showing how the magnitude of indicator's variable is able to influence latent variable. Information about value of loading factor and $\mathrm{R}^{2}$ from structural estimation can be seen on Table VI.

Table VI. Value of Factor Loading and $\mathbb{R}^{2}$ 
The relationship between independent latent variables (MKT) and dependent latent variables (PKK) as well as manifest variables and its latent variables other than structural estimation value could be seen on test of t-value on diagram of path. Value of t-value could be seen on Figure 2.

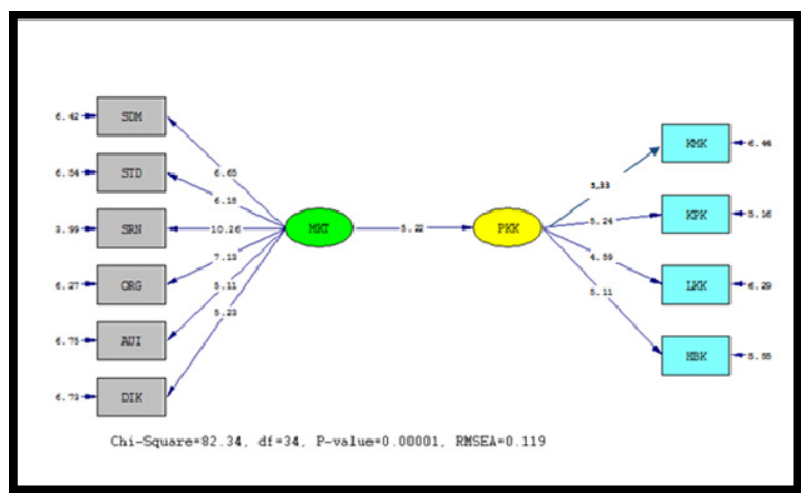

Figure 2 Value of T-value Test of Structural Model

It shows that all indicators forming latent variables is feasible (t-value >1.96), so that the model doesn't need to be modified.

Based on structural estimation value, it is obtained structural mathematical notations and mathematical model notation of manifest variables measurement on latent variables as follow:

1. Structural mathematical notation of research $\mathrm{PKK}=0,86 \mathrm{MKT}+0,265$

The notation explains that PKK is affected by MKT's implementation as magnitude of 0.86 in scale measurement error as $0.265(26.5 \%)$. The result is feasible because relationship between MKT's independent latent variable and PKK's dependent variable, based on t-value, as magnitude of 5.22 in feasible degree $5 \%(>1.96)$, therefore it yields fit model.

2. Mathematical model notations of manifest variable measurement on latent variable.
a. $\mathrm{SDM}=0,63 \mathrm{MKT}+0,60$
b. $\mathrm{STD}=0,59 \mathrm{MKT}+0,65$
c. $\mathrm{SRN}=0,86 \mathrm{MKT}+0,25$
d. $\mathrm{ORG}=0,66 \mathrm{MKT}+0,56$
e. $\mathrm{AUI}=0,51 \mathrm{MKT}+0,74$
f. $\mathrm{DIK}=0,52 \mathrm{MKT}+0,73$
g. $\mathrm{KMK}=0,57 \mathrm{PKK}+0,68$
h. $\mathrm{KPK}=0,76 \mathrm{PKK}+0,43$
i. $\mathrm{LJK}=0,61 \mathrm{PKK}+0,63$
j. $\mathrm{HBK}=0,72 \mathrm{PKK}+0,48$

\section{Goodness Of fit statistic / GOF}

After conducting model estimation, the next step is conducting fitness test to check compatibility level of data on the model, validity and reliability of measurement model and coefficient feasibility of structural model of the

\begin{tabular}{|l|l|l|l|}
\hline $\begin{array}{l}\text { Research } \\
\text { Variables }\end{array}$ & $\begin{array}{l}\text { Indicators } \\
\text { Measured }\end{array}$ & $\begin{array}{l}\text { Factor of } \\
\text { Loading }\end{array}$ & $\boldsymbol{R}^{\mathbf{2}}$ \\
\hline MKT & Human Resources & 0,63 & 0,396 \\
\cline { 2 - 4 } & Standard & 0,59 & 0,352 \\
\cline { 2 - 4 } & Tools & 0,86 & 0,748 \\
\cline { 2 - 4 } & Organization & 0,66 & 0,442 \\
\cline { 2 - 4 } & Internal Audit & 0,51 & 0,255 \\
\cline { 2 - 4 } & Training and & 0,52 & 0,266 \\
\hline PKK & Education & & 0,321 \\
\cline { 2 - 4 } & Work Ability & 0,57 & 0,571 \\
\cline { 2 - 4 } & Work Willing & 0,76 & 0,367 \\
\cline { 2 - 4 } & Work Environment & 0,61 & 0,518 \\
\cline { 2 - 4 } & Work relations & 0,72 & . \\
\hline
\end{tabular}

research obtained. The summary of the test using SEM's analysis method can be seen on Table VII.

The next step is evaluation of measurement of fitness test, that is, validity and reliability evaluation. Validity evaluation is based on t-value of loading factor $\geq 1,96$ and value of loading factor of each indicator $\geq 0,5$. Based on path diagram on model estimation, it can be known that $\mathrm{t}$-value of each indicator $\geq 1.96$ and value of each research indicator $\geq 0.5$. Whereas reliability evaluation, it is based on value of construct reliability and variance extracted. A construct has a feasible reliability value if construct reliability $\geq 0.70$ and variance extracted $\geq 0.5$. Construct reliability value of MKT's latent variable PKK's latent variable are as 0.801 and 0.821 . Whereas value of construct variability of MKT's and PKK's latent variable are 0.629 and 0.676 respectively. Therefore it can be known that research model is feasible as a whole, and not necessary to re-specify, the model can directly be interpreted to path diagram, as shown on Figure 1.

Test of research hypothesis is viewed based on $\mathrm{t}$ value. Based on the use of SEM's analysis method, it can mark the significance of research model statistic by verifying research hypothesis.

\section{$\mathrm{H}_{1}$ : There is positive relationship between implementation of Total Quality Management and Employees Productivity in PT XYZ. \\ MKT's independent latent variables give} positive influence on PKK's dependent latent variable as magnitude of 0.86 . It means feasible because there is relationship between MKT's independent latent variable and PKK's dependent variable as 5.22 (t-value $>$ t-table 1 , 96). Therefore, $\mathrm{H} 1$ is accepted.

$\mathbf{H}_{2}$ : There is positive relationship between human resources, standard, tools, organization, internal audit, as well as training and education on TQM's implementation.

Human resources, standard, tools, organization, internal audit, as well as training and education 
give positive influence on MKT as latent variable, based on loading factor's value $>0.5$ and $\mathrm{t}$-value which is owned by each indicator is greater than t-table (1.96). Therefore, $\mathrm{H}_{2}$ is accepted.

Table VII. Fitness Test of Research Model

\begin{tabular}{|c|c|c|c|}
\hline $\begin{array}{c}\text { Measure of } \\
\text { GOF }\end{array}$ & Level of Fitness & $\begin{array}{c}\text { Estimation } \\
\text { yield }\end{array}$ & Conclusion \\
\hline $\begin{array}{c}\text { Chi- } \\
\text { square/df }\end{array}$ & $\leq 3$ & 2,4 & Good \\
\hline RMSEA & $\begin{array}{c}0,08<\text { RMSEA } \leq 0,1 \\
(\text { marginal fit })\end{array}$ & 0,119 & Marginal \\
\hline GFI & GFI $\geq 0,9($ good fit $)$ & 0,854 & Marginal \\
\hline AGFI & AGFI $\geq 0,8($ good fit $)$ & 0,764 & Marginal \\
\hline NFI & NFI $\geq 0,9($ good fit $)$ & 0,884 & Marginal \\
\hline NNFI & NNFI $\geq 0,9$ (good fit $)$ & 0,904 & Good \\
\hline CFI & CFI $\geq 0,9($ good fit $)$ & 0,927 & Good \\
\hline
\end{tabular}

\section{$\mathbf{H}_{3}$ :}

\begin{abstract}
There is a positive relationship between employees willing to work, employees ability, work environment, and work relationship on employees productivity (PKK) in PT XYZ.
\end{abstract}

Work willing, work ability, work environment, and work relations give positive influence on PKK as latent variable based on loading factor $>0.5$ and value of $\mathrm{t}$-value which is owned by each indicator is greater than value of t-table (1.96). In other words, $\mathrm{H}_{3}$ is accepted.

\section{CONCLUSION}

Elements of TQM's implementation in PT XYZ, e.g. human resources, standard, organization, internal audit, and training \& education, give positive influences on the success of TQM's implementation. Tool is the most predominant element in order to influence the success of TQM's implementation in PT XYZ, the better development and management of rubber's tool, so that TQM's implementation in PT XYZ will be more effective. It also has positive influences on employees productivity. They are obtained from structural model equation of research that is $\mathrm{PKK}=0,86 \mathrm{MKT}+0,265$. Whereas, improvement of employees productivity in PT $\mathrm{XYZ}$ is measured by indicator of employees willing to work, employees ability, work environment, and work relations. Based on SEM's analysis method, concluded that employees willing is the most predominant indicator in affecting employees productivity which indicates that the better employees willing then employees productivity will improve. Therefore, PT XYZ still has to improve the development and management on the tool which has been available to support an effective TQM's implementation.

\section{ACKNOWLEDGMENT}

The authors are would like to thank all respondents who participated in the study.

\section{REFERENCES}

[1] Besterfield, Dale H, Quality Control. New York: Prentice Hall, 2003.

[2] Muhandari, $\mathrm{T}$ dan Kadarisman, Food Quality Assurance System. Bogor: Bogor Agriculture Institute's Press, 2008.

[3] Ibrahim, B. Total Quality Management: "A Guide to Face Global Competition". Jakarta: Djambatan, 2000.

[4] Sinungan, Muchdarsyah, Productivity: "What and How", Jakarta: Bumi Aksara, 1995.

[5] Sugiharti, Dian Eka Sri, Analysis of Integrated Quality Management on Vegetable Distributor Company, CV Bimandiri Lembang West Java. Master Thesis. Bogor: Agriculture Faculty of Bogor Agriculture Institute, 2005.

[6] Melisa, Restu Putri, Influence of Total Quality Management Implementation on Employees of GIANT Hypermarket BOTANI SQUARE BOGOR. Master Thesis. Bogor: Economic Faculty of Bogor Agriculture Institute, 2009.

[7] Rendy, Raden Ahmad. An Integrated Quality Management Implementation on Organic Vegetables Company (Case Study on Frida Farm, Lembang Subdistrict, West Java). Master Thesis. Bogor: Agribusiness Department, Management Faculty of Bogor Agriculture Institute, 2009.

[8] Chairany, Nurul. 2011. The Influence of Total Quality Management on Company's Performance through Leadership and Employee's Productive Behavior. Master Thesis. Makassar: Engineering Faculty of Hasanuddin University.

[9] Indraswari, Influence of ISO 9001: 2000 Quality Management System Implementation on Employees Productivity of PT PN VIII Gunung Mas Bogor. Master Thesis. Bogor. Faculty of Economic and Management, Bogor Agriculture Institute, 2007.

[10] Sinulingga, Sukaria, Research Methods. Medan: USU Press, 2011.

[11] Sugiyono, Methods of Qualitative Research. Bandung: Alfabeta, 2004. 


\title{
ICMIIT2014
}

\section{Speaker's Certificate}

\author{
Prepared for
}

\section{Nilda Tri Putri}

Andalas University

\section{ICMIT14-P-0082: The Effect of TQM Implementation Towards Productivity of Employees Using Structural Equation Modeling (SEM) Analysis Method in PT XYZ Nilda Tri Putri, Haesti Sujita Darma Andalas University, Indonesia}

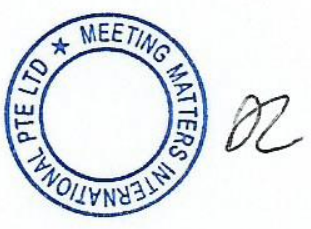

for Kah-Hin Chai,

Organizing Chair, Organizing Committee

September, 2014 


\section{Scopus Preview \\ Search Sources Alerts Lists Help \\ Login}

\section{Author details}

The Scopus Author Identifier assigns a unique number to groups of documents written by the same author via an algorithm that matches authorship based on a certain criteria. If a document cannot be confidently matched with an author identifier, it is grouped separately. In this case, you may see more than 1 entry for the same author.

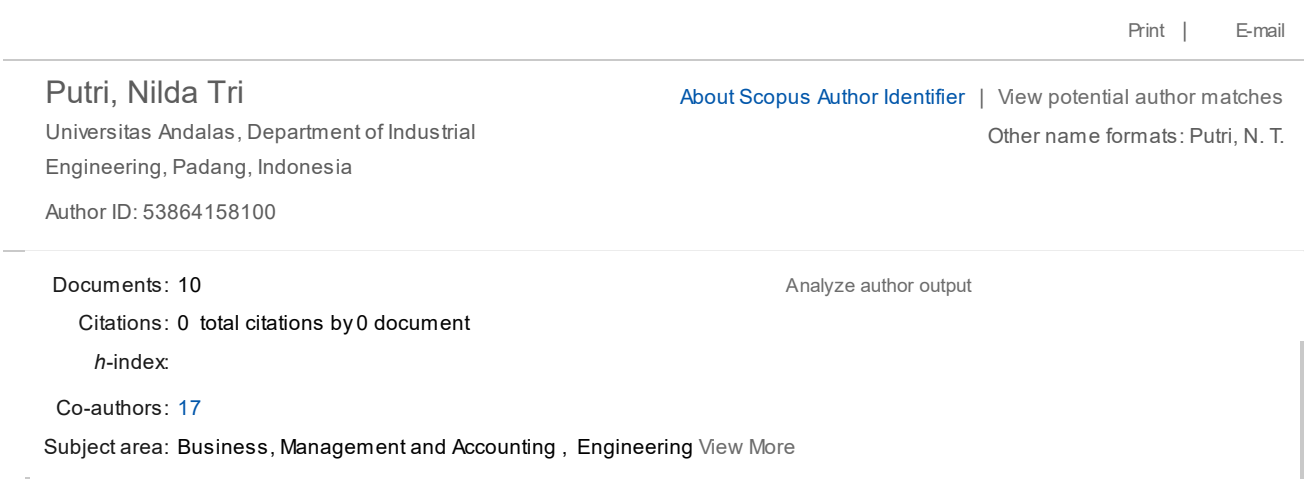

10 Documents | 17 co-authors

10 documents view in search results format Sort on: Date Cited by

Export all | Add all to list | Set document alert | Set document feed

Redesign of thresher machine for farmers using rapid upper limb assessment (RULA) method
Putri, N.T.,Susanti, L., 2016 IEEE International Tito, A., Sutanto, A. Conference on Industrial Engineering and

Engineering Management
View abstract | Related documents

The role of an organizational culture and individual towards knowledge management practice in cement industry
Putri, N.T.,Kurnia, S. 20162016 IEEE International $\quad 0$

Conference on

Management of

Innovation and

Technology, ICMIT 2016
Follow this Author Receive emails when this author publishes new articles

Get citation alerts

Add to ORCID

Request author detail corrections

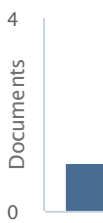

201
2016

$$
\text { Years }
$$

Documents

Author History

Publication range: 2011 - 2016

References: 140

\section{Source history:}

Lecture Notes in Eectrical Engineering View documents IEFE International Conference on Industrial Engineering and Engineering Management View documents IOP Conference Series: Materials Science and Engineering View More

\section{Show Related Affiliations}

View abstract | Related documents

Comparison of Quality Engineering Practices in Malaysian and Indonesian Automotive Related Companies

View abstract | Related documents

Design of quality system documentation in hydrotiller production unit as improvement of quality management system in small and medium enterprise

View abstract | Related documents

Facility layout design on the agricultural machinery industry

\section{Putri, N.T.,}

Sha'Ri Mohd, Y. Irianto, D.

Putri, N.T., Retha, F.,

Yusof, S.M.

Putri, N.T.,Fithri, P. Taufik, M.

2015 Lecture Notes in

Computer Science
2016 IOP Conference Series: Materials Science and Engineering

View abstract | Related documents

\begin{tabular}{llrl}
\hline $\begin{array}{l}\text { An inventory system of packaging materials: Case study } \\
\text { at PT. Djambi Waras Jujuhan }\end{array}$ & $\begin{array}{l}\text { Putri, N.T.,Jonrinaldi, } \\
\text { Risa Noviani, Y.R. }\end{array}$ & $\begin{array}{l}\text { Lecture Notes in } \\
\text { Electrical Engineering }\end{array}$ & 0
\end{tabular}

\footnotetext{
View abstract | Related documents
}

The effect of TQM implementation towards productivity of Putri, N.T.,Darma, H.S. 2014 ICMIT $2014-2014$ IEEE employees using Structural Equation Modeling (SEM) analysis method in PT XYZ

International Conference

on Management of

Innovation and

Technology

View abstract | Related documents

\begin{tabular}{|c|c|c|c|c|}
\hline $\begin{array}{l}\text { The Delphi hierarchy process-based study of quality } \\
\text { engineering in Malaysia and Indonesia automotive } \\
\text { companies }\end{array}$ & $\begin{array}{l}\text { Putri, N.T., } \\
\text { Mohd. Yusof, S., } \\
\text { Irianto, D. }\end{array}$ & 2014 & TQM Journal & 0 \\
\hline \multicolumn{5}{|l|}{ View abstract | Related documents } \\
\hline $\begin{array}{l}\text { Strategic road performance model: An approach to } \\
\text { sustainable facilities management }\end{array}$ & $\begin{array}{l}\text { Kamil, I.,Alias, B., } \\
\text { Mohammed, A.H., } \\
\text { Putri, N.T.,Meilani, D. }\end{array}$ & 2014 & Jurnal Teknologi & 0 \\
\hline View abstract | Related documents & & & & \\
\hline
\end{tabular}

Journal of

0


An empirical investigation of quality tools and techniques practices in Malaysia and Indonesia automotive

View abstract | Related documents

Display: $20 \quad$ results per page $\quad \square$ Page 1

Top of page

The data displayed above is compiled exclusively from articles published in the Scopus database. To request corrections to any inaccuracies or provide any further feedback, please contact us (registration required). The data displayed above is subject to the privacy conditions contained in the privacy policy.

$\begin{array}{ll}\text { About Scopus } & \text { Language } \\ \text { What is Scopus } & \text { 日本語に切り替える } \\ \text { Content coverage } & \text { 切换到简体中文 } \\ \text { Scopus blog } & \text { 切換到繁體中文 } \\ \text { Scopus API } & \end{array}$

Customer Service

Scopus API

Privacy matters

\section{ELSEVIER Terms and conditions Privacy policy}

Copyright () 2017 Elsevier B.V. All rights reserved. Scopus ${ }^{\circledR}$ is a registered trademark of Elsevier B.V.

Cookies are set by this site. To decline them or learn more, visit our Cookies page. 